\title{
OD ŠUME DO INTARZIJE
}

\section{FROM FOREST TO MARQUETRY}

\section{Margarita BEGO}

\section{SAŽETAK}

Cilj ovoga rada je pokazati važnost očuvanja šuma, kao jednog od temelja kulturne baštine Republike Hrvatske. Šume su prirodno bogatstvo i izvor drva koje se primjenjuje u restauraciji drvnih predmeta visoke umjetničke vrijednosti, $s$ naglaskom na posebne restauratorske vještine, umjetničke izrade intarzija. Furniri kao drvni proizvodi, dobiveni tehnološkim procesima su u sredini tehnološkog procesa između održavanja šuma i izrade intarzija. Drvo je materijal koji se koristi kroz povijest, te mu se pravilnim održavanjem i uporabom produljuje životni vijek. Intarzija je umjetnička tehnika koja se intenzivno razvila u 13. stoljeću, a potječe još iz doba Egipta i Rima. Sastoji se od jednostavnog umetanja materijala za ukrašavanje površina ili predmeta. Furniri su najvažniji element za izradu intarzije. Tijekom povijesti razvilo se nekoliko načina izrade, od kojih se izdvajaju sljedeće tehnike: Tarsia certosina, Tarsia geometrica, Tarsia a toppo, Tarsia a Incastro nazvana Boulleova tehnika. U radu je prikazana najjednostavnija ručna izrada intarzije sa zadanim motivom. Prikazom jednostavne intarzije opisan je proces od izbora furnira do izrade intarzije Boulleovom tehnikom, te zaključkom da fina umjetnost počiva i razvija se iz šume.

KLJUČNE RIJEČI: šuma, furniri, intarzije, tehnike intarzija

\section{UVOD}

\section{INTRODUCTION}

„Šuma je najveći dar koje ima čovječanstvo.“

Gaj Plinije Sekund, zvan Stariji (23.-79. godine)

Podaci koji se mogu pronaći za potrebe istraživanja sežu u daleku prošlost, pokušavajući time prikazati važnost prirodnog bogatstva i resursa bez kojih današnjice ne bi bilo i o čemu se danas ne bi pisalo, istraživalo i uspoređivalo. Iz tih osnovnih postavki može se zaključiti da

očuvanje šuma i zaštita okoliša predstavlja preopsežan problem te su svi napori, konferencije, radionice i drugi skupovi premalo da bi se osvijestilo stanovništvo svijeta o važnosti očuvanja prirodnih resursa koji se uništavanju. Uz trenutno najveći problem u očuvanju planeta Zemlje, očuvanja okoliša, neminovno je očuvanje šuma i njenih općekorisnih funkcija, kao što su osiguravanje svježeg zraka i čiste vode, kao i izvora drvne sirovine. Utjecaj šume na čovjekov okoliš je iznimno velik (Visković,2001).
Šume su krhak ekosustav, a njihovo održivo upravljanje s pažljivim korištenje resursa, ključni su za borbu protiv klimatskih promjena i doprinos napretku i dobrobiti sadašnjih i budućih generacija. Stalno se ističe da šume pokrivaju trećinu Zemljine kopnene površine, obavljajući životne vitalne funkcije, čime su biološki najraznovrsniji i jedan od najsloženijih ekosustava na kopnu. Osim što su šume pluća svijeta one su i ukupnost bioloških dobara sjedinjenih u šumske ekosustave pa su, uz morske ekosustave, globalno najvažniji dijelovi prirode (Burne 1994; Sekuliš,2001).

Kroz povijest čovjek se koristio drvom za različite potrebe, od drva kao materijala za paljenje vatre, do građenja stambenih nastamba i plovila te izrade drvenih predmeta, oruđa $i$ alata. Sve do danas, drvo je jedan od najviše upotrebljavanih materijala. Ljudi su vrlo rano na Sredozemlju počeli iskorištavati šumu. Djelatnošću čovjeka šuma uzmiče pred šikarom i makijom (Braudel, 1996). Šume su od davnine bile najveće blago Republike Hrvatske. Zbog koristi koju je stanovništvo imalo od šuma, one postaju simbol slobode (Kolar-Dimitrijević, 2008). 
Šume su, kao što je općenito poznato, najvrjedniji obnovljivi prirodni resurs i opće dobro od iznimnog interesa za Republiku Hrvatsku. Šumarstvo je znanost, struka i umijeće gospodarenja i očuvanja šuma i staništa, odnosno cijelog šumskog ekosustava, za trajnu dobrobit društva, okoliša i privrede (Vrbek, 2011).

U dalekoj prošlosti Dalmacija i dalmatinski otoci bili vrlo šumoviti, o čemu svjedoče i statuti pojedinih dalmatinskih gradova (Ninski iz 1103. godine, Korčulanski 1214. godine, Splitski 1240. godine, Dubrovački 1272. godine, Trogirski 1332. godine), iz kojih je vidljivo da se već tada brinulo za očuvanje šuma (Ištvanić,2001). Još je Polibije tvrdio da je otok Hvar u vrijeme ratovanja Rimljana protiv Demetrija Hrvatskog 219. godine pr. n. ere bio pokriven šumama. Na to upućuje i najstariji naziv za Hvar - Pityeria iz kojega se može zaključiti da je otok $u$ antičko vrijeme bio pokriven borovim šumama (grč. Пitus, lat. pinus bor) (Ištvanić, 2001).

Šume i šumska zemljišta u Republici Hrvatskoj, dobra su od općeg interesa te uživaju posebnu zaštitu države i pod budnom su brigom šumarskih stručnjaka. Koriste se pod uvjetima i na način koji su propisani Zakonom o šumama. Cilj gospodarenja šumama u Republici Hrvatskoj je održivo i skladno korištenje svih funkcija šuma i trajno poboljšavanje njihova stanja (URL3).

Hrvatska je danas vrlo šumovito područje, iako to u manjoj mjeri vrijedi za primorske krajeve. Šume i drvo imaju važnu ulogu u tradicijskoj kulturi Hrvata te s njima povezanim drevnim vjerovanjima (Vinšćak, 2002). Može se zaključiti da je bogatstvo koje Republika Hrvatska ima u šumama bilo neizmjerno važno u prošlosti te bi se to svakako trebalo održati i za buduće generacije. Stoga se u Zagrebu 1996. godine osniva Akademija šumarskih znanosti s ciljem okupljanja šumarskih znanstvenika. Cilj je poticanje razvoja šumarstva kao bitne gospodarske grane Republike Hrvatske (Prpić i sur., 1976).

Predmet ovoga rada je istraživanje primjene umjetničke tehnike izrade intarzija uz korištenje visokovrijednih furnira u svrhu ukrašavanja površina ili predmeta. Prikazan je razvoj tehnika intarzija kroz povijest, te razvoj alata $\mathrm{i}$ strojeva koji su se istovremeno razvijali stvarajući impozantne predmete umjetničke vrijednosti. No, da bi se predmeti od drva s intarzijama izradili, ili u današnje vrijeme restaurirali, potrebno je imati na umu da mogućnost stvaranja takvih predmeta koji su dio kulturne baštine ne bi bio moguć bez očuvanja šuma. Stoga bi cilj ovoga rada bio pokazati važnost očuvanja šume, uz plansku proizvodnju furnira, te uporaba furnira za restauratorske tehnike izrade predmeta umjetničke vrijednosti, intarzija. Na osnovi saznanja iz istraživanja, moglo bi se zaključiti da fina umjetnost izrade intarzija započinje $u$ šumi.

\section{POVIJEST RAZVOJA PROIZVODNJE FURNIRA \\ 2. HISTORY OF VENEER PRODUCTION DEVELOPMENT}

Povijesni razvoj šumarstva na području Republike Hrvatske dijeli se na četiri povijesna razdoblja. Prvo povijesno razdoblje predstavlja uzimanje dobara iz šuma bez ograničenja i bez ikakvog plana. To razdoblje traje do 12. stoljeća kada se prvi put javljaju gradski statuti, od kojih je najstariji očuvani Statut lige kotara ninskog, a koji je napisan 1103. godine. Ti statuti ograničavali su korištenje šumskih dobara. Drugo razdoblje označava korištenje šuma prema potrebama i mogućnostima, bez plana i programa. To razdoblje traje do kraja 17. stoljeća. U trećem razdoblju uvodi se plansko korištenje šuma, ali i program za zaštitu i obnovu postojećih i već devastiranih šumskih područja koje po prvi put donosi Mletačka Republika. Takvo gospodarenje šumama zadržalo se do posljednjeg razdoblja koje počinje polovicom 20. stoljeća te se i danas provodi. Četvrto razdoblje označava korištenje znanstvenog pristupa pri gospodarenju šumama te samim time šumski ekosustav postaje glavni čimbenik održivog prirodnog okoliša. Šuma u zadnjem razdoblju gleda se kao osnovni čimbenik za opstanak prirodnog ekosustava (Krpan, 2013).

Ukupna površina šuma i šumskih zemljišta u Hrvatskoj iznosi 2688687 ha, što je 47\% kopnene površine države. Od toga je 2106917 ha ili 78\% u vlasništvu Republike Hrvatske, a prema podacima Šumskogospodarske osnove područja 2006. - 2015. na teritoriju Republike Hrvatske 1.1.2006. ukupno je bilo 581.770,30 ha šuma šumoposjednika, a Programi za gospodarenje šumama šumoposjednika bili su izrađeni za 42.741,68 ha ili $7 \%$. Uređeno je bilo 26 od tada ustrojene 562 gospodarske jedinice, ili 5 \% (Šumskogospodarska osnova 2016-2025).

Bez šuma ne bi bilo predmeta izrađenih od drva, posebno analizirajući artefakate umjetničke i estetske vrijednosti. Da bi neki drveni artefakt bio opet u funkciji, te ostao sačuvan budućim generacijama kao bogato naslijeđe kulturne baštine jednog geografskog područja, potebno je učiniti sve što je moguće da mu se ne promijene svojstva, koja ga čine tako jedinstvenim i posebnim. Vrlo je važno da dijelovi predmeta koji su uništeni ili nedostaju budu zamijenjeni ili umetnuti istim materijalima, odnosno istom vrstom drva, bilo da se radi o masivnom drvu ili furniru. Furniri su glatki, tanki listovi drva, debljine od 0,4-10 mm, koji se izrađuju cijepanjem, piljenjem, rezanjem ili ljuštenjem (Mešić,1998).

Na samom početku u procesu proizvodnje furnira potrebno je pripremiti trupce na određenu dimenziju, odnosno, skratiti ih, a zatim specijaliziranim strojevima, horizontalnom jarmačom raspiliti na polovine, pri čemu se 
proizvode bočnice, ili pak na četvrtine pri čemu se dalje piljenjem dobivaju blistače i polublistače. Nakon početnog piljenja dobivaju se komadi drva, naziva polovnjaci ili fličevi koji se zatim spuštaju u jame za parenje. Parenje polovnjaka, odnosno furnira radi se u svrhu omekšavanja drva kako bi se olakšalo daljnje rezanje i skidanje kore s bočnih strana (Krpan 1951).

Za proizvodnju furnira neophodno je koristiti zdrave, jedre trupce, ravne žice, koje nisu napali insekti, koji imaju određenu debljinu (od $45 \mathrm{~cm}$ srednjeg promjera na više, bez kore) i dužinu od $2 \mathrm{~m}$ na više. Za izradu furnira koriste se i trupci s nepravilnom žicom drva, od kojih se raspiljivanjem dobivaju posebne dekorativne šare drva, što je za izradu drvenih predmeta s intarzijama od posebnog značaja. Ručna proizvodnja furnira stara je nekoliko tisuća godina.

Prvi počeci uporabe furnira potječu iz faraonskog doba. U grobnicama egipatskih faraona nađeni su ukrasi izrađeni od furnira (oko 1500 g. pr.Kr.), a poznavali su ga i upotrebljavali za furniranje također stari Grci i Rimljani (Skliar, 2005). Furnir je sa listićima slonove kosti, abonosa, srebra i zlata, služio za izradu intarzija u drvu. Krajem 18. i početkom 19. stoljeća furnir se upotrebljavao u finijim izradama kao jedan od glavnih materijala za intarzije (Jovanović,1948). Po Pliniju za proizvodnju furnira najbolja je klenovina, šimširovina, jasenovina i limunovo drvo (tako su Rimljani nazivali drvo atlaskog čempresa, Callitris quadrivalvis). Tvornička proizvodnja furnira počinje tek u 18. Stoljeću, dok se prije toga proizvodnja furnira svodila na primitivan način. Oko 1650. godine javlja se najprimitivnija pila jarmača koja pili trupce gibanjem okvira, odnosno jarma u koji je upeto do dvadeset lisnih pila.Od 1777. godine u uporabu ulazi i kružna pila koja radi na principu okretanja noža sa zupcima koji penetriraju u drvo i režu ga te tračna pila tek 1808. godine. Prvi podaci o furnirskoj pili pojavljuju se 1812. godine kao patent jednog francuskog inženjera, a u proizvodnju ulazi 1825. godine. Zbog velikog gubitka kvalitetnog drva, ovu tehnologiju zamjenjuje stroj za rezani furnir koju patentira 1834. godine francuski inženjer Charles Picot. Uporaba ovog stroja počinje tek od 1860. godine.

Prvi patent stroja za ljuštenje furnira izdan je u USA 1840. godine (Knežević, 1966). Garand 1844. godine patentira ljuštilicu koja je uz nož imala i potiskivač, s mogućom dužinom trupca do $2 \mathrm{~m}$ i brzinom ljuštenja od $4-5 \mathrm{~m} / \mathrm{min}$. Nagli razvoj industrije furnira počinje krajem 19. stoljeća (Krpan, 1970). U Njemačkoj je 1843. godine. podignuta prva tvornica za proizvodnju piljenih furnira. Današnji tip strojeva za rezanje furnira počeo se primjenjivati oko 1875. godine. Prva tvornica furnira u nas počela je radom 1913. godine u Slavonskom Brodu (Krpan, 1951).

Tek od polovice 19.stoljeća počinje uporaba furnira za izradu većih, ljepših površina namještaja. Naši preci izra-

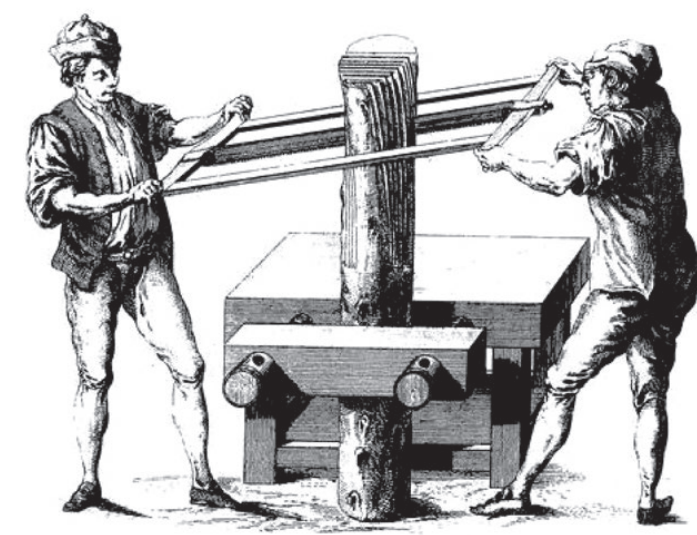

Slika1. Piljenje furnira prije izuma stroja (URL 1)

Figure 1. Veneer sawing before the invention of the sawing machine

đivali su tanke daščice cijepanjem, te ih trljali naročitim glatkim kamenom da bi dobili jednaku debljinu i glatkoću (Bajalo,1958).

Prednost furnira pred masivnim drvom je višestruka: iskorišćivanje skupljih vrsta drva u mnogo manjoj količini, iskorišćivanje savijenih i nepravilnih komada drva, kao i korijena drva, nalijepljeni furnir štiti drvo, te se u slučaju oštećenja mijenja samo furnir, zatim mogućnost izrade puno većih ravnih površina i kao najvažnije slaganje šara drva u pravilne slike (Jovanović, 1948).

Prekrasne teksture dobivaju se poprečnim presjekom drvaraznih nepravilnosti u rastu. Uporaba ovakvog drva je nemoguća za izradu namještaja od masivnog drva, jer drvo uslijed nepravilnosti puca, vitoperi se, uvija i savija, pa je za namještaj neupotrebljiv (Bajalo, 1953). Koriste se takođe i trupci s nepravilnom žicom koji daju posebne dekorativne šare. Industrija furnira obuhvaća proizvodnu tehniku za izradu dekorativnih visoko kvalitetnih površinskih materijala koji su načinjeni od pravoga drva.

Furniri se klasificiraju prema vrsti drva, tehnici izrade, ravnini reza, načinu obrade, načinu slaganja, debljini i načinu primjene. Prema načinu primjene furniri se dijele na plemenite (dekorativne) i slijepe (konstrukcijske). Plemeniti furniri su piljeni i ljušteni furniri koji se koriste za oplemenjivanje lica namještaja, uređenje interijera, za intarzijske radove i dr. Tu dolaze do izražaja estetska svojstva drva; boja, tekstura i sjaj. Debljina ovih furnira iznosi 0,5 - 1,0 $\mathrm{mm}$, izuzetno $2,0 \mathrm{~mm}$. Slijepi furniri služe kao podloga plemenitom furniru da bi se podloga učinila glađom i da se spriječi raspucavanje plemenitog furnira. Slijepi furnir je deblji i lošije kvalitete.

Slijepi furniri izrađuju se od topolovine, lipovine, vrbovine, johovine, platanovine, jelovine, smrekovine i bukovine, a koriste se za izradu uslojenog drva, zbog čega im debljina najčešće iznosi 2,5, 3 i 3,5 mm. Pod najčešće korištene vrste drva za plemenite furnire spadaju hrastovina, brijestovina, 
bijela jasenovina, bijela javorovina, bukovina i crna topolovina. Pri makroskopskoj indetifikaciji osnovnih svojstava i karakteristika obavlja se povećanje lupom 5-10 puta (Grael i Lecumberri, 2006).

Kroz povijesne kulturne epohe drvo je uvijek intenzivno privlačilo čovjekovu pozornost, nekada kao čuvanje autentičnosti njegove materije, a nekada uz eksperimentiranje sa tehnikama njegovog ukrašavanja (duborez, intarzija, oslikavanje, marketerija, furniranje i dr.). Neke vrste drva pružaju originalne estetske efekte, te su kao takve u tankim slojevima lijepljene na pojedine dijelove namještaja. Ovakav način primjene furnira bio je ograničeno zastupljen i predstavljao je pojedinačni umjetnički rad (Gluhaić, 2015).

\section{PREGLED PRIMJENE INTARZIJA KROZ POVIJEST \\ 3. AN OVERVIEW OF THE APPLICATION OF MAROUETRY THROUGH HISTORY}

Razvojem restauratorskih tehnika, s posebnim osvrtom na tehniku izrade intarzija, promatrano kroz povijesna razdoblja, ipak se proizvodnjom furnira uvelike olakšao rad majstora stolara, a danas i umjetnika restauratora. Pripremljeno drvo predviđeno za korištenje listova furnira u izradi umjetničkih slika - intarzija, izrezano u furnir može predstavljati ogromnu umjetničku i estetsku vrijednost artefakta ili predmeta. Tako se može reći da nepravilnosti u rastu drva, $u$ ovome slučaju, nude bogatstvo lijepih slika koje se dobiju slaganjem tako dobivenih furnira. Dva furnira istog presjeka pravilno postavljeni jedan pored drugoga mogu dati dekorativnu, simetričnu sliku neočekivanog efekta. U slučaju odgovarajuće teksture drva, šteta je izrezati ga u piljenice, jer se na taj način dobiva manje dekorativnih površina drva. Rezanjem takvog drva u furnire dobije se veći broj šarenih, tankih, drvenih površina. Furnir omogućava raznovrsno sa-

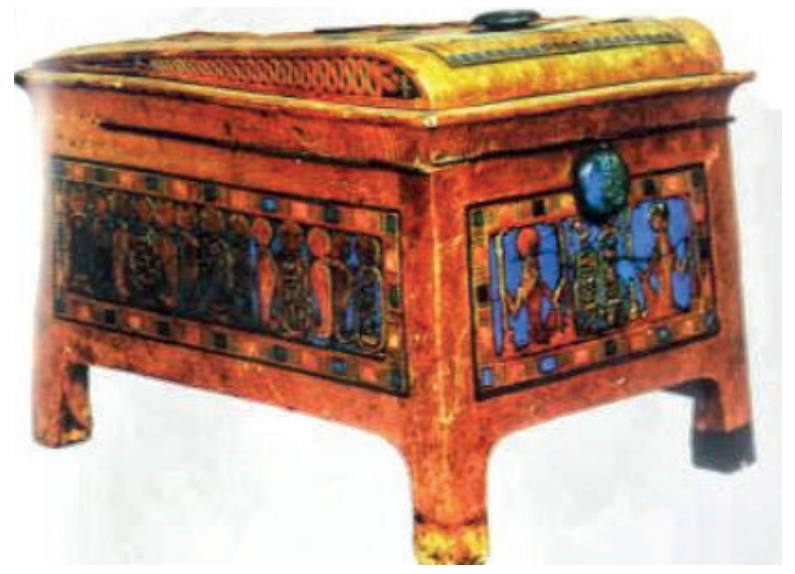

stavljanje, pa njegove slike i šare, ukusno složene, daju izrađenim predmetima vrlo lijep i živahan izgled (Bajalo,1953).

Istraživanjem tehnika intarzija kroz povijest može se reći da postoji velik broj načina izrade, odnosno više tehnika kojima se umjetnici mogu koristiti, pa tako i kombinirati tehnike i time stvarati i svoj način izrade.

Povijest intarzije kao tehnike počinje još u doba antičke Grčke koja daje primjere ove tehnike rađene u mramoru. Primjeri tehnike mogu se naći i u antičkom Rimu pod nazivom opus sectile koji je najčešće rađen u mramoru, staklu i biseru. Prvi poznati tragovi proizvodnje i uporabe furnira nalaze se Starom Egiptu, na raznim predmetima od drva iz kraljevskih grobnica. Furniri su korišteni kao intarzije, zajedno sa slonovačom, dragim kamenjem i metalima, kao dekorativno sredstvo za postizanje umjetničkih efekata (Paolini, 2017). U Egipatskom muzeju u Kairu nalaze se uz intarzije i furnirani stolovi, kreveti, stolice i ostali namještaj iz tog vremena. Slični predmeti su nađeni u staroj Grčkoj i područjima Antičkog Rima. Kod Rimljana se susreće furnir za slične svrhe kod stolova, koji su u njihovom domaćinstvu zauzimali središnje mjesto (Nikolić, 1988). Grobna škrinja iz Tutankamonova groba u Dolini kraljeva je drvena škrinja, koja je prekrivena listićima od zlata i ukrašena različitim ornamentalnim uzorcima te jarkim bojama koje se ističu (Skliar, 2005).

Furnir, inkrustacija i intarzija se smatraju istom tehnikom ukrašavanja iz razloga što se svi sastoje od tankih vrjednijih materijala nanesenih preko drvene podloge. Tehnikom intarzije se umeću komadići drva na tvrdu podlogu stolova, ormara i sl. Smatra se da riječ 'intarsia' dolazi od latinske riječi 'interserere’ što znači „umetnuti“.

Kada je Egipat u 7. stoljeću došao pod Arapsku vlast, umjetnost intarzije i umetanja komadića drva proširili su se svijetom. Umjetnost intarzije već je bila usavršena u islamskoj Sjevernoj Africi prije nego li ju je kršćanska Europa upo-

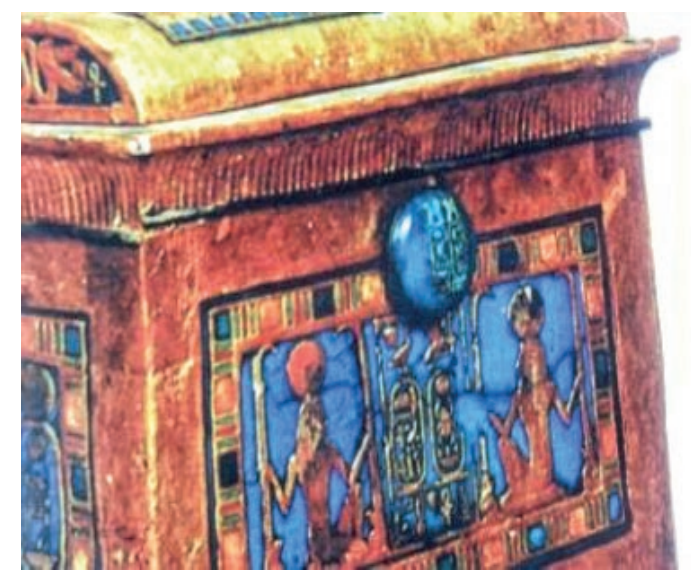

Slika 2. Grobna škrinja iz Tutankamonova groba u Dolini kraljeva; drvo s listićima zlata i plavim intarzijama od fajanse (1323. pr. Kr.) lzvor: Skliar, 2005. Figure 2. The chest found in Tutankhamun's tomb in the Valley of the Kings; wood with golden leaves and blue faience marquetry (1323 BC) Source: Skliar, 2005 
znala preko Sicilije. Umjetnost je daljnje razvijena u gradu Sieni od njezinih majstora na katedrali Orvieto oko 1330. godine, gdje se i figurativna intarzija prvi put pojavila te nastavlja u 15. stoljeće. U sjevernu Italiju dolazi krajem 15. stoljeća, šireći se prema svim većim gradovima u Njemačkoj i dolazi do Londona preko flamanskog majstora krajem 16. stoljeća (Jordano, 2011).

Intarzija se od pojave kršćanstva do Srednjeg vijeka nije primjenjivala. Tek se ponovno javlja u 13. stoljeću kada se umjetničkom tehnikom počinje ukrašavati crkveni namještaj. Primjenjivanjem religioznih motiva, kao i profanih poput plodova, ljudskih i životinjskih likova i slično, dostiže svoj vrhunac za vrijeme perioda talijanske renesanse. Nakon tog razdoblja primjena intarzije u Italiji opada, ali se širi ka zapadu i sjeveru Europe. U to vrijeme posebno se ističe izrada intarzija u Nizozemskoj koja je iz kolonija uvozila egzotične vrste drva korištene za ukrašavanje predmeta od drva. Nizozemski majstori imali su velik utjecaj na francuske umjetnike, s naglaskom na majstora intarzija AndréCharlesa Boullea. Tako francuski majstori intarzija počinju koristiti prirodne tonove u izradama samostalnih kompozicija ili u ukrašavanju namještaja (Skliar,2005).

\section{METODE IZRADE INTARZIJA 4. METHODS OF MAROUETRY}

Tehnike izrade intarzija koje su se razvile kroz povijest mogu se podjeliti na pet najznačajnijih: Tarsia Cerostina (još 350 B.C.), Tarsia Geometrica (14. stoljeće), Tarsia a Tappo (16.stoljeće), Tarsia a Incastro (17. stoljeće) te Piece by Piece (18. stoljeće). Ostale tehnike se mogu definirati kao kombinacija osnovnih tehnika i njihove varijacije.

Uporaba drva odnosno furnira za izradu dekorativnih elemenata javlja se pod nazivom Tarsia Certosina. To je tehnika koju su umjetnici koristili i u 18. Stoljeću, a danas se koristi kako bi se restaurirali nedostajući dijelovi marketerije. Predstavljala je umetanje dijelova furnira u šupljine u obliku kanala ili drugih oblika izrezbarenih u površinu u koju se kasnije umetnu odgovarajući komadi drva ili drugih materijala. Furniri koji se koriste za ovu tehniku mogu biti debljine i do $5 \mathrm{~mm}$, a mogu se rezati dlijetom ili pilom koja je pogodnija za izradu. Najviše se koristilo drvo orahovine, a motivi koji su bili prikazivani su najčešće bili geometrijski. Izrada tehnike bila je najzastupljenija na španjolskom i talijanskom području. Padom Rimskog carstva prestaje biti zastupljena, ali se ponovno javlja u Italiji u 14. stoljeću te se naziva Tarsia Geometrica, te više ne predstavlja umetanje furnira u šupljine već prekrivanje cijele površine komadima furnira. Umjetnici su uz pomoć dlijeta rezali komade drva i slagali ih u geometrijske forme, zbog čega i dobiva naziv Geometrica, a danas se može susresti i pod nazivom frisage. Prilikom izrade furniri su najčešće piljeni mehanički, pomoću kružne pile.
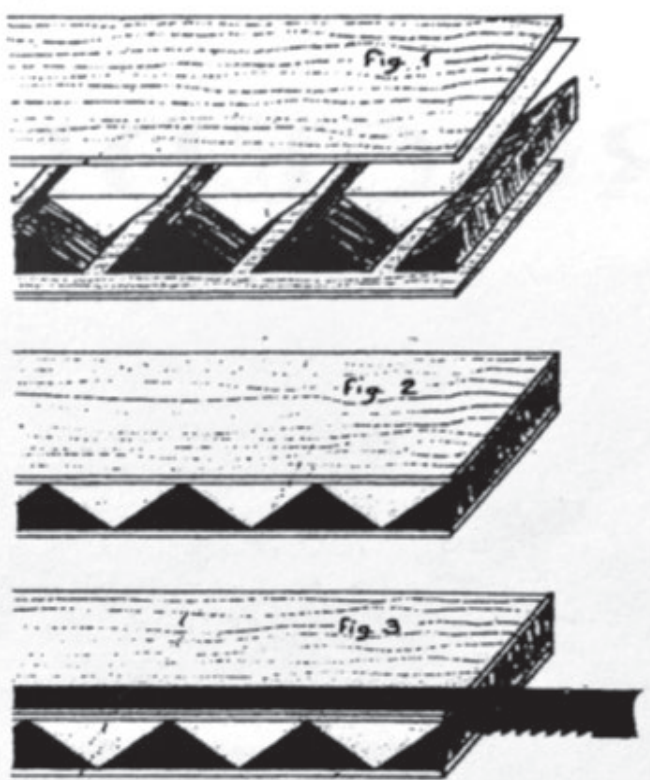

Slika 3. Tarsia a Toppo, Izvor:Ramond,1989

Figure 3. Tarsia a Toppo, Source: Ramond, 1989

Kao posljedica zamorne pripreme sitnih komadića furnira u 16. stoljeću dolazi do pojave nove tehnike intarziranja, odnosno tehnike pod Tarsia a toppo, koja predstavlja ručno pripremanje furnira, odnosno slaganje komada drva.

Obilježava je slaganje i lijepljenje drvenih štapića tako da se dobije određeni motiv, nakon čega se reže na tanke trake koje se kasnije umetnu ili lijepe na površinu kako bi se stvorio željeni motiv. Zatim se tako izrezani i pripremljeni oblici drva lijepe u zamišljeni motiv po redu, za što su majstori koristili životinjsko tutkalo.

Usavršavanje intarziranja rezultiralo je ne samo bržim i jednostavnijim načinom izrade, već i sposobnošću za stvaranje kompleksnijih dekoracija te su se tjekom 16. stoljeća mogli vidjeti motivi poput građevina, ulica, stupova, balkona, vr-
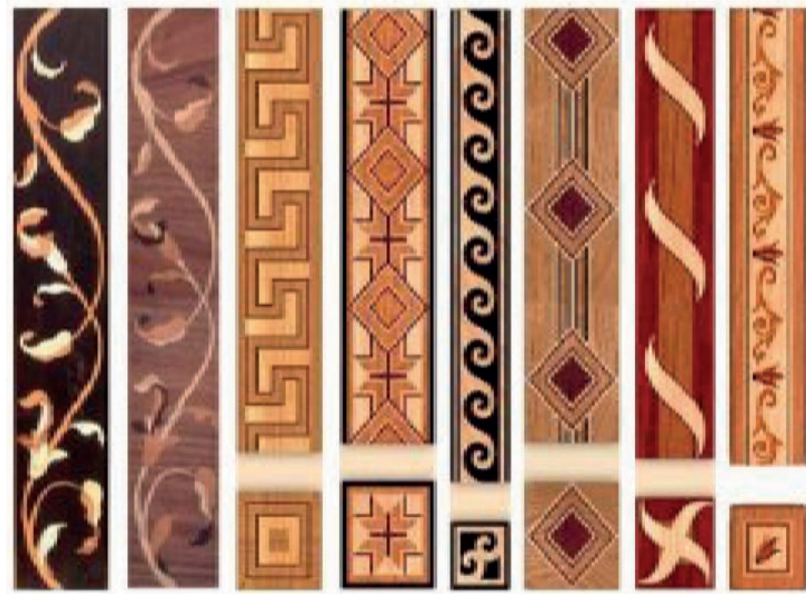

Slika 4. Tarsia a toppo motivi, Izvor:URL 6 Figure 4. Tarsia a toppo motives,Source:URL 6 


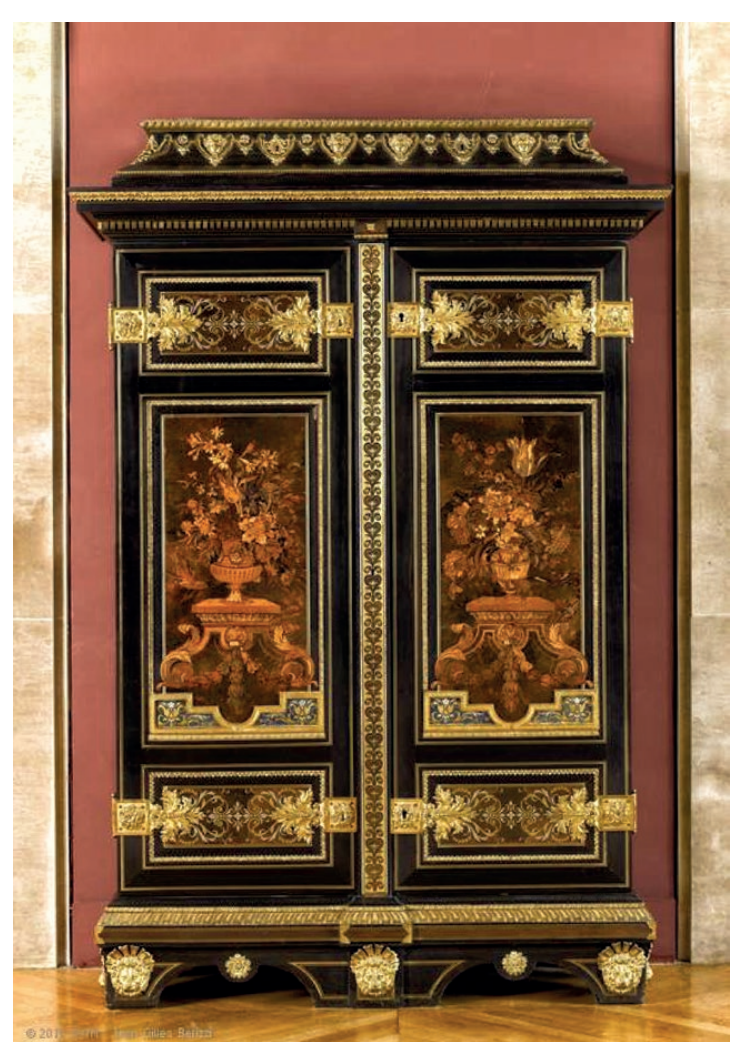

Slika 5. Kabinet u Boulle stilu, André-Charles Boulle, Louvre (URL 5) Figure 5.Boulle style cabinet, André-Charles Boulle, Louvre

tova i slično. Osim u Italiji tehniku su usavršavali i njemački majstori te se gradovi Nuremberg, Augsbourg i Dresden ističu kao centri ove umjetnosti (Ramond, 1989).

Razvoj nove tehnike koja je obilježila 17. stoljeće u Njemačkoj pod imenom Tarsia a Incastro predstavlja spajanje dva ili više furnira, te rezanje s oštricom prateći linije crteža.

Izrađuje se slaganjem furnira različitih vrsta drva jedan na drugi, tako da se nakon rezanja dobiva više mogućnosti slaganja furnira u motiv. Izrada se može svesti na osam koraka od kojih je prvi priprema odnosno odabir furnira. Dobiveni komadi furnira se potom slažu u željeni motiv, čime se po- stiže isticanje kontrasta boja. Tehniku je usavršio AndréCharles Boulle. Pa je poznata je i pod imenom Boulle technique. Majstor André-Charles Boulle razvija ovu tehniku do savršenstva i stvara remek-djela zbog čega je tehnika prepoznatljiva i po njegovom imenu. Potpisi umjetnika na djelima zahtijevaju su tek od 1741. godine, pa se njegovim djelima ne može naći njegovo ime. Njegovo djelo u Louvru nosi oznaku umjetnika Jean-Henri Riesenera koji je krajem 18. stoljeća imao čast restaurirati ga.

\section{INTARZIJE DANAS 5. MARQUETRY TODAY}

Ono što je najvažnije i bez čega se ne može govoriti o intarziji kao umjetničkom stvaranju je poznavanje materijala koji je osnova za ovu granu umjetnosti, a to je drvo. Kod tehnike intarzija najvažniji je odabir vrste drva, te način na koji su ti komadi piljeni i uklapani. Danas drvene intarzije se najčešće rade od furnira debljini $0,6-0,8 \mathrm{~mm}$ umetanjem komadića furnira raznih boja, oblika i veličina, koji su u istoj ravnini s podlogom. Za konsolidiranje željenih cjelina koriste se papirnate trake s nanosom lijepila, kao i specijalni sintetički topivi konac (taljiva nit). Spajanjem ili sklapanjem furnira dobivaju se trodimenzionalne slike nalik mozaicima koje oplemenjuju predmete na poseban način. Veće površine se za podlogu lijepe toplom ili hladnom metodom $u$ specijalnim prešama. Simulacijom u odgovarajućem računalnom programu može se čak dočarati i finalna slika intarzirane površine, pa čak i odabir kombinacija furnira. Od nedavno se za izradu furnira koristi „laserska“ tehnologija koja ubrzava procese izrade željenih formi-izrada replika.

Strojno (CNC, laser) i ručno izrađene intarzije nije moguće uspoređivati, po umjetničkoj i ekonomskoj vrijednosti, no to ne znači da strojno izrađen namještaj s intarzijom nije kvalitetan i vrijedan. Predmet brojnih istraživanja je rezanje mlazom vode (water jet). To je relativno nova tehnologija u obradi furnira, a spada u nestandardne postupke
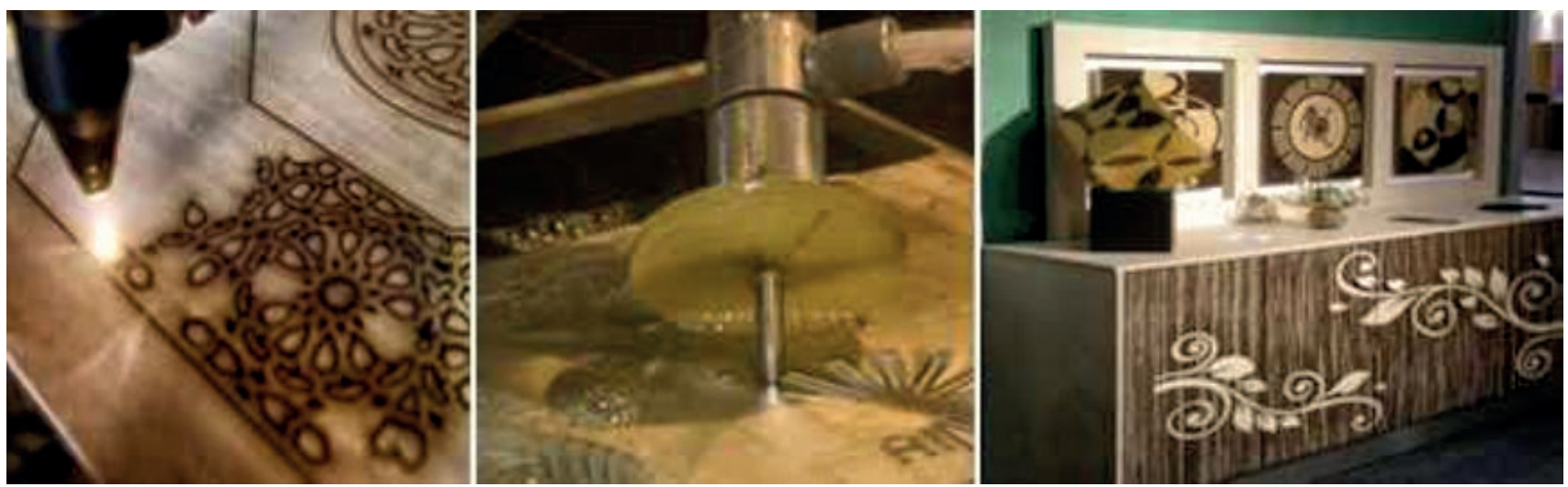

Slika 10. .Piljenje furnira CO2 laserom,vodenim mlazom i izgled gotovih intarzija (Elit, Italija) Izvor: Hlock i sur, 2011

Figure 10. CO2 laser veneer sawing, water jet and the appearance of finished marquetry (Elite, Italy) 
obrade. Rezanje mlazom vode omogućava rezanje kompleksnih oblika (Hlock i sur.,2011).

Promatrajući prekrasno izrađene intarzirane površine mnogi ni ne pomisle otkud sve te prelijepe, bogate, ukrašene slike na drvenim površinama. Da nema prekrasnih furnira koji se dobiju preradom trupaca, iz šumskih sastojina ni potrebnog umijeća stvaranja istih ne bi bilo. Moglo bi se jednostavno zaključiti da nema šume ne bi bilo ni furnira ni intarzija. Umjetnost izrade intarzija seže u daleku prošlost i otkrivaju kolika su bila potrebna znanja i vještine uz vrlo primitivne alate, za izradu takvih predmeta što se danas vidi na mnogim umjetničkim artefaktima pohranjenim u muzejima i posebnim zbirkama Danas, uz svu tehnologiju izrada intarzija i dalje zahtijeva znanje, vještinu i strpljivost u restauraciji drvenih predmeta kulturne baštine.

Zahvaljujući širokom spektru vrijednih vrsta drva iz bogatih i dobro očuvanih šumskih sastojina, danas nam intarzije zaustavljaju dah svojim očaravajućim vizualnim identitetom.

\section{ALATI ZA INTARZIJE 6. MARQUETRY TOOLS}

Intarzija se radila alatom koji se kroz povijest mijenjao. Prve tehnike izrade bile su cijepanje daščica debljine 3 ili $4 \mathrm{~mm}$, koje su se cijepale u radijalnom smjeru drva te se stanjivale trljanjem kamenom. Upotrebljavao se nož s kratkom oštricom i usadom, toliko dugim da se oslanja na rame. Uz nož koristili su se usko dlijeto i tanko šilo, a s vremenom se počela upotrebljavati pila. Nakon toga furniri se počinju dobivati pomoću strojeva i nož s dugim usadom je zamijenjen nožem s kratkim usadom. Prednost izrade furnira strojevima je izražena tekstura, sjaj i boja drva koja je odmah uočljiva umjetniku. Izbor drva za izradu intarzija je velik, ali je uz sjaj, teksturu i boju važno da se drvo previše ne uteže, ne lomi prilikom rezanja i ne propušta ljepilo na lice furnira.

Razvojem tehnike i njenim dopunjavanjem te stvaranjem različitih mogućnosti izrade dolazi i do stvaranja različitih alata i strojeva koji omogućavaju jednostavniju izradu. Stoga se potrebna oprema može podijeliti na male i velike alate te strojeve i daska za rezanje (Slikae 6.,7.).

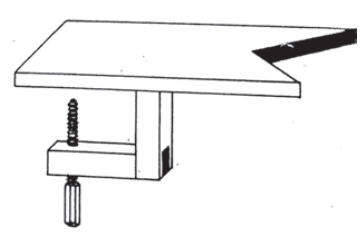

Slika 6. Daska za rezanje furnira

Figure 6. Veneer cutting board

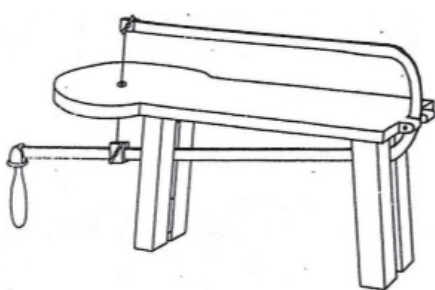

Slika 7. Fretsaw, pila za rezanje na ručnom principu rada

Figure 7. Fretsaw, hand-held cutting saw
U 19. stoljeću nastaje veći stroj pod imenom Marquetry cutter's donkey ili klupa za marketeriju koja se i danas koristi u školama poput Ecole Boulle u Parizu. (URL 4). Nastala je još u ranijem stoljeću te se razvijala dok nije dobila strukturu koja omogućava umjetniku što lakšu izradu (Slika 8). Rad na ovom stroju omogućava rezanje oko dvanaest furnira, te izradu motiva dovedenu do visoke razine preciznosti. Drugi velik stroj osim klupe za marketeriju je Jigsaw ili pila koja se sastoji od vertikalnog okvira u koji je horoizontalno postavljeno postolje za rad kroz čiji centar prolazi pila, čije se kretanje proizvodi pomicanjem pedale koja je smještena u donjem djelu stroja (Slika 9). Prvi modeli nastaju u 19. stoljeću i konstrukcija im je bila izrađena od drva, dok kasniji modeli dobivaju metalnu konstrukciju koja može imati i tzv. swan-neck oblik vertikalnog dijela stroja, kao i motorni način rada. Kod nekih modela ugrađeni su i kompresori koji odstranjuju višak drvne prašine, a ujedno i hlade drvo i prste umjetnika, s obzirom da su oni blizu same oštrice za rezanje (Ramond, 1989).

Promatrajući prekrasno izrađene intarzirane površine mnogi ni ne pomisle otkud sve te prelijepe, bogate, ukrašene slike na drvenim površinama. Da nema prekrasnih

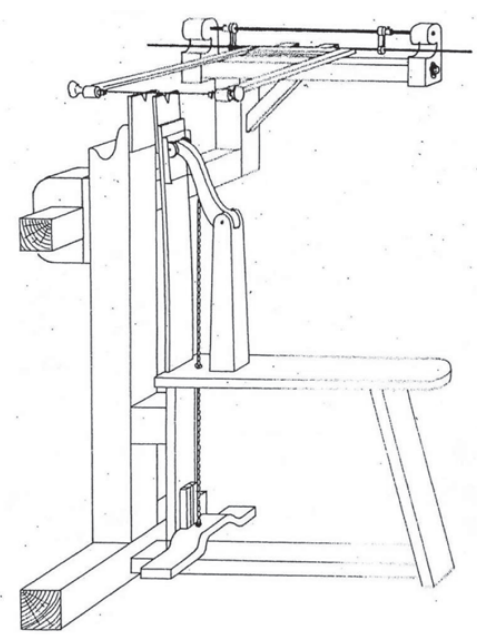

Slika 8. Klupa za marketeriju Izvor:URL 4

Figure 8. Marquetry cutter's donkey, Source: URL 4

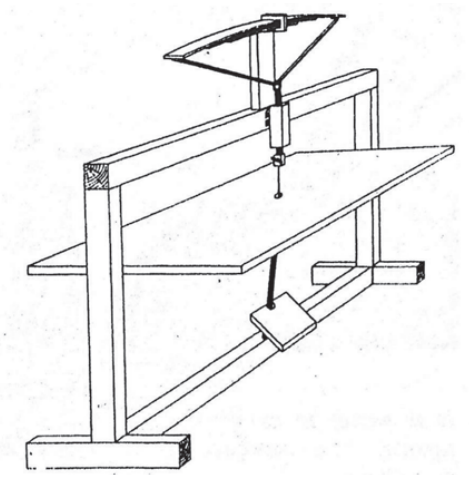

Slika 9. Jigsaw 


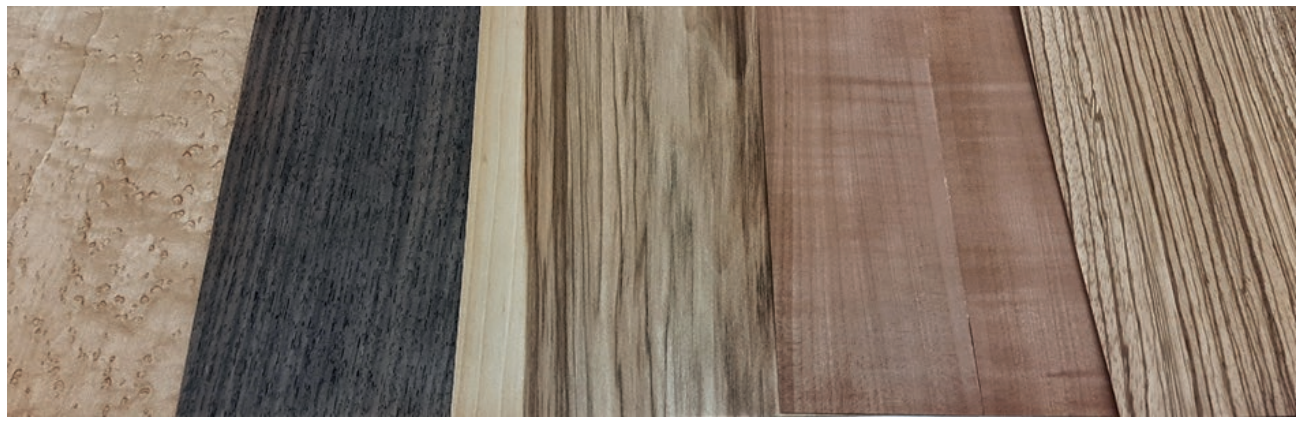

Slika 11. Odabrani furniri za izradu intarzije : ptičji javor, palisander, orah, kruška i zebrano (Bego)

Figure 11. Selected veneers for marquetry: birdseye maple, rosewood, walnut, pear wood and zebrawood (Bego)

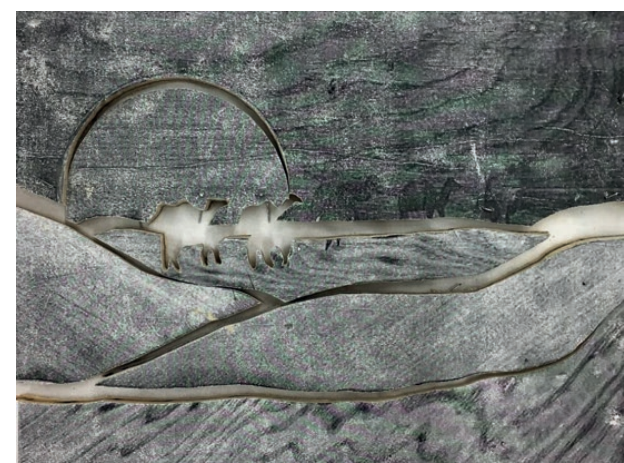

Slika 12.

Figure 12.

Izvor: S.Stevanović, Source

furnira koji se dobiju preradom trupaca, od drveća koje raste u šumi, ni potrebnog umijeća stvaranja istih ne bi bilo bez šuma. Moglo bi se jednstavno zaključiti da nema šume ne bi bilo ni furnira ni intarzija. Umjetnost izrade intarzija seže u daleku prošlost i otkrivaju kolika su bila potrebna znanja i vještine uz vrlo primitivne alate za izradu takvih predmeta, što se danas vidi na mnogim umjetničkim artefaktima pohranjenim u muzejima i posebnim zbirkama $\mathrm{Da}$ nas, uz svu tehnologiju izrada intarzija i dalje zahtijeva znanje, vještinu i strpljivost u restauraciji drvenih predmeta kulturne baštine.

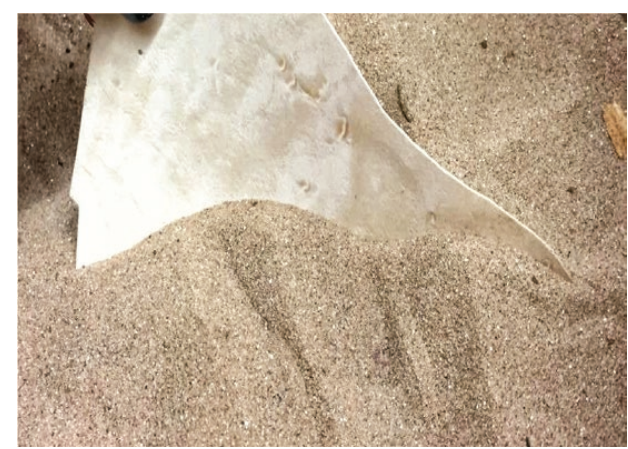

Slika 14.

Figure 14.

Izvor: S.Stevanović, Source

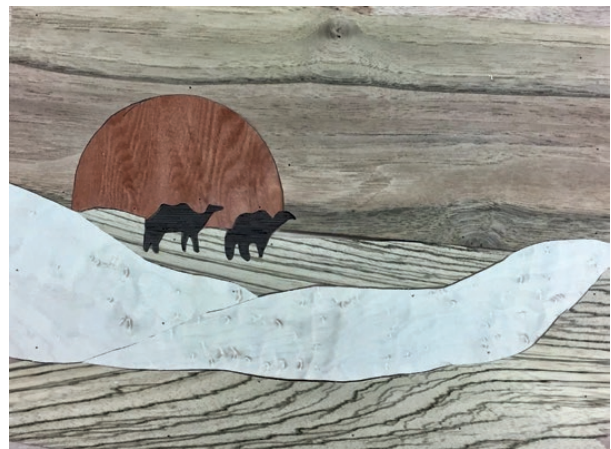

Slika 13.

Figure 13.

\section{IZRADA INTARZIJA}

Najvažniji dio za razumijevanje i usvajanje tehnike intarziranja je sama izrada koja će omogućiti sljubljivanje materijala i alata, zbog boljeg i bržeg savladavanja samog postupka izrade intarzije. Kratkim prikazom izrade najjednostavnije intarzije Boulleovom tehnikom približiti će se postupak izrade. Suha metoda izrade intarzije, odnosno marketerije je slaganje listova furnira koji se pričvrste malim čavlićima te se izrađuju pilom, potom zalijepe na željenu drvenu površinu.

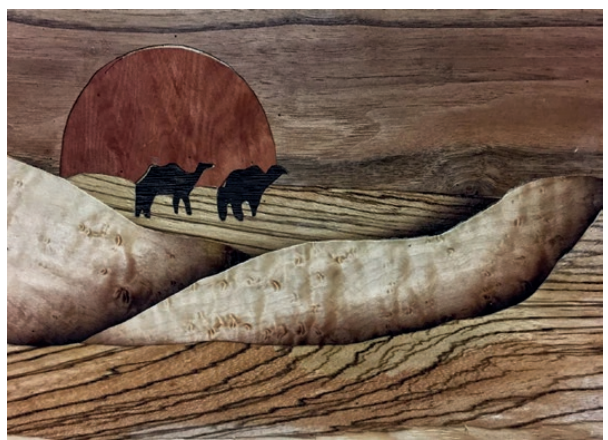

Slika 15.

Figure 15. 
Prije samog početka izrade intarzije važno je izabrati odgovarajuće listove furnira koji će istaknuti unaprijed odabran motiv na pravi način. Izabrani furniri za izradu jednostavne intarzije u ovom slučaju su drvo kruške, palisandera, oraha, zebrana i ptičjeg javora.

Odabrani furniri su izrezani u veličini podloge koja će biti nositelj intarzije. Zatim se komadi furnira slažu na tanku drvenu ploču postavljeni tako da određeni furnir leži na željenom segmentu motiva i pokrivaja se drugom tankom drvenom pločom na koju se postavlja crtež. Čavlićima se pričvrste svi složeni slojevi furnira po rubovima i kutovima tako da budu čvrsto spojeni.

Nakon piljenja čavlići se skidaju, slojevi izrezanih furnira prema slici se odvajaju kako bi se odabrali najljepši dijelovi furnira koji se slažu u motiv (Slika 12). Potom se krajevi furnira zagrijavaju u vrućem pijesku (Slika 14) kako bi se postigao efekt sjene (Slika 13).

Kada se svi željeni komadi furnira osjenče u pijesku slijedi lijepljenje na podlogu. Podloga i izrezani komadi furnira premazani su otopinom tutkala koja je prethodno zagrijana te se na podlogu slažu furniri, folija i druga daska, s ciljem da se što bolje stisnu i zalijepe furniri. Sve se pričvrsti stegama i ostavi da se osuši.

Nakon što se tutkalo osuši, stege i daska se odvajaju i ostaje samo intarzija koja je spremna za završnu obradu površine (Slika 15). Potrebno je prvo površinu zagladiti, za što su potrebni oštrica i brusni papir. Oštricom se odstrani sav višak furnira na spojevima dva spojena furnira, dok se brusnim papirom cijela površina učini jednakom i glatkom.

Kada je površina jednaka, ravna i glatka slijedi nanošenje politure pomoću pamuka i tkanine kako bi izrađena slika intarzija dobila željeni sjaj i površinsku zaštitu. S obzirom da se drvo prilikom promjene temperature i vlage uteže i širi, kao i prilikom nanošenja tutkala i lijepljenja između dvije daske može doći do neispunjenog prostora kod spojeva dva komada furnira. Tada se nanosi kit koji će se uklopiti s bojom i teksturom furnira.

Prikazom izrade jedne vrlo jednostavne intarzije Boulleovom tehnikom otvaraju se mnoge mogućnosti u istraživanju i primjeni izrade drugih tehnika koje su se koristile kroz prethodna povijesna razdoblja.

Izrade intarzije zahtijeva veliko umijeće, vještine i znanje koje se prenosi generacijama kroz povijest. Restauracija stola iz 19. stoljeća, povijesnog razdoblja klasicizma iz privatne zbirke, zahtijevala je upravo spomenute vještine. Intarzija na površini stola izrađena je Boulleovom tehnikom, a prikazuje geometrijsku sliku koja zbog specifičnog slaganja furnira vizualno prikazuje intarziju izgledom kocki u 3D dimenziji (Slika 16).

Restauratorski zahvati na klasicističkom stolu pokazali su se neočekivano zahtjevni, što je nemoguće unaprijed pred-

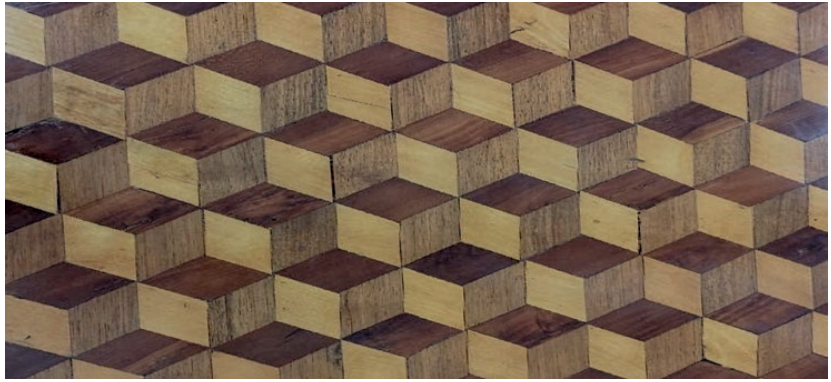

Slika 16. Dio intarzije površine stola za vrijeme restauriranja Figure 16. Part of the marquetry on the table surface during the restoration Izvor: M. Bego, Source: M. Bego

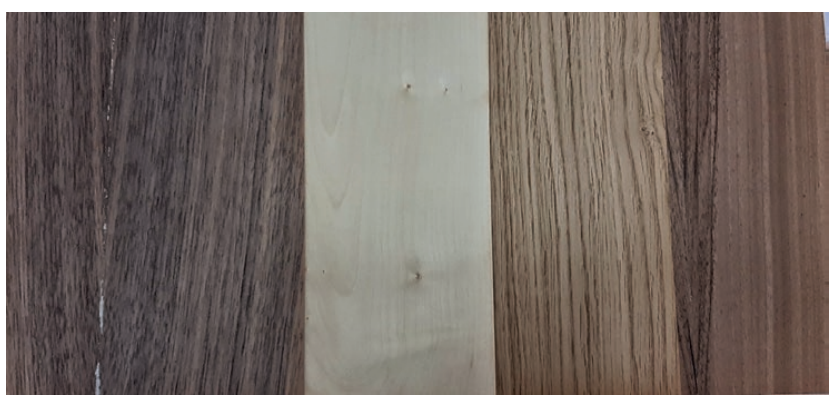

Slika 17. Furniri za restauriranje intarzije: američki orah, javor, hrast i euroski orah, Izvor: M. Bego

Figure 17. Veneers used for marquetry restoration: American walnut, maple, oak and European walnut

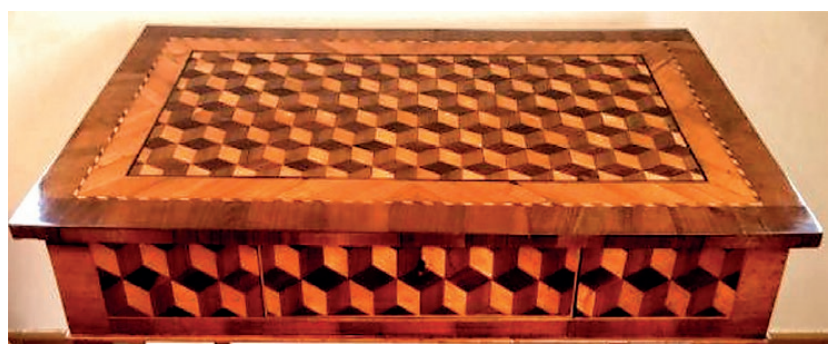

Slika 18. Intarzirana ploča stola i stranice nakon restauriranja Izvor: M. Bego

Figure 18. Inlaid table top and side panel after restoration Source: M. Bego

vidjeti prilikom početka opisa zatečenog stanja predmeta, što ponekad produlji vrijeme trajanja rada na predmetu koji se restaurira.

\section{PRIMJENA INTARZIJA NA NAMJEŠTAJU IZ KULTURNO - POVIJESNOG MUZEJA U DUBROVNIKU}

\section{APPLICATION OF MARGUETRY ON FURNITURE FROM THE CULTURAL AND HISTORICAL MUSEUM IN DUBROVNIK}

Nakon kratkog povijesog pregleda intarzija i jednostavne izrade intarzije, zanimljivo je upoznati se i s namještajem 


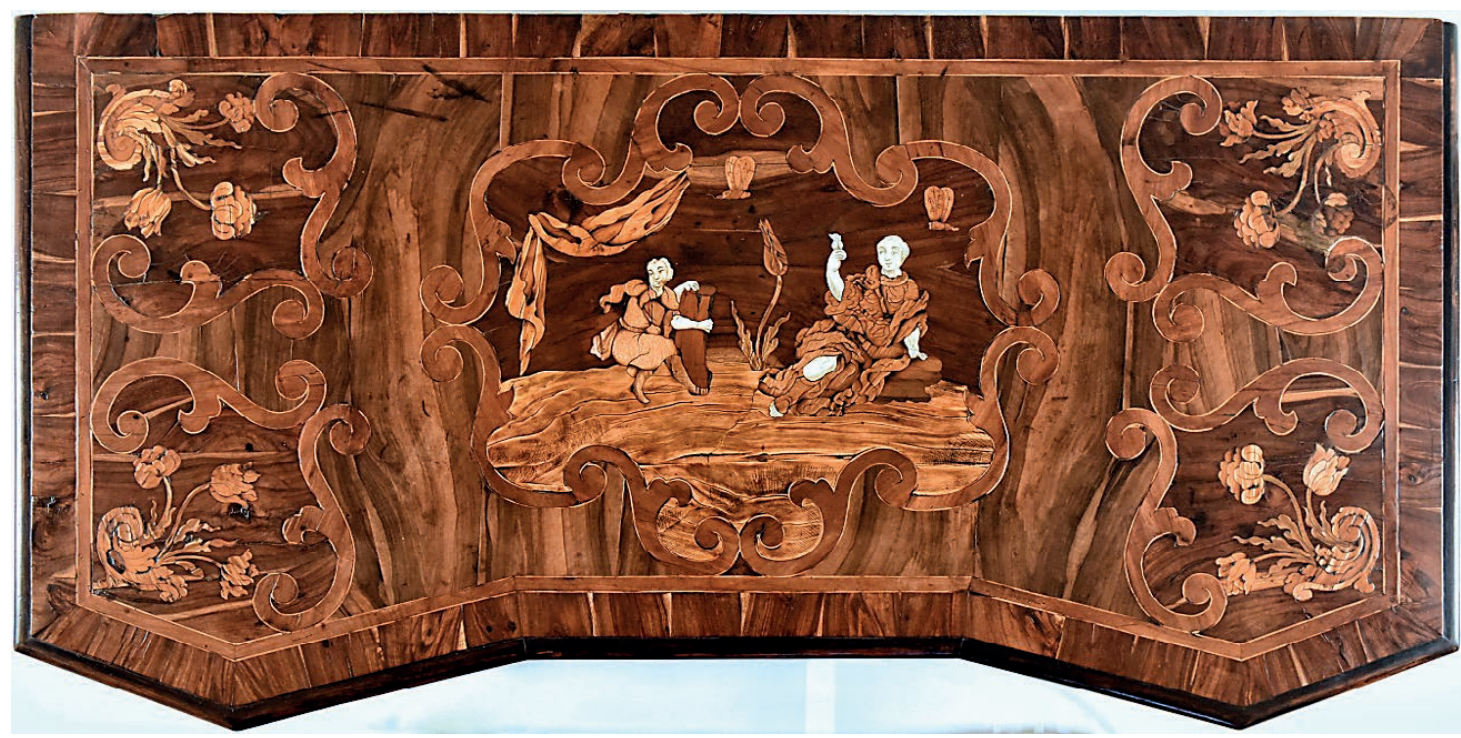

Slika 19. Gornja ploča komode iz Kulturno-povijesnog muzeja iz Dubrovnika

Figure 19. Top plate of the chest of drawers from the Cultural History Museum in Dubrovnik

na kojemu su izrađene intarzije. Bez sumnje vrlo zanimljivi primjeri takvih predmeta od drva su oni visoke dodatne vrijednosti iz muzeja ili privatinih zbirki. U Kulturno-povijesnom muzeju u Dubrovniku je u stalnom postavu namještaj s vrlo bogatim intarzijama, od kojih će komoda i ormar biti opisani i prikazani fotografijama u ovome radu.

Komoda (inv. br. DUM KPM P-364) pripada u povijesno razdoblje kraj 17. stoljeća. Komoda je izrađena u Padovi, odakle je dopremljena u Dubrovnik. Osnovna konstrukcija komode je izrađena od jelovine, a furniri od kojih je ukrašena su od drva rogača, masline, badema, javora, trešnje, kruške, tise, šimšira i komadića bjelokosti. Osim tehnike intarzije korištena je i tehnika graviranja užarenom iglom kojom je postignut efekt sjenčanja rubova furnira. Intarzija na središnjem dijelu ladica prikazuje ženski lik u poluležećem položaju, odjeven u klasičnu odjeću bogate draperije.

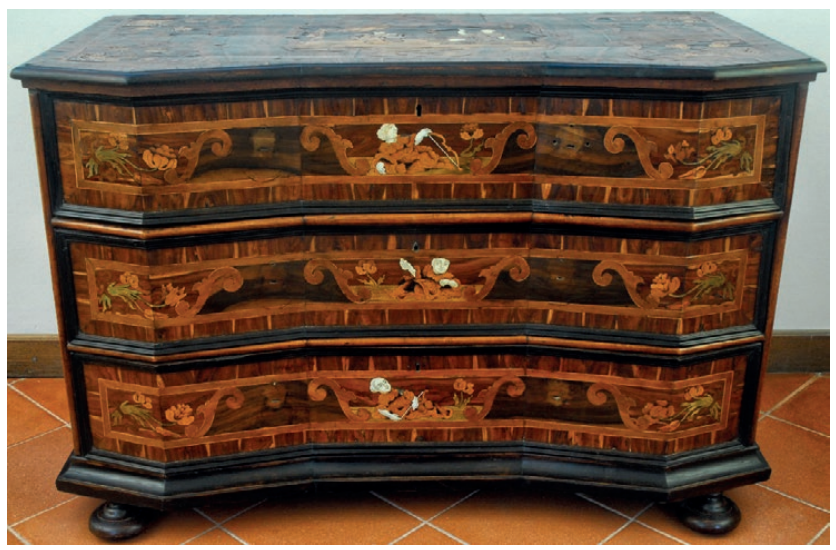

Slika 20. Prednja strana komode s ladicama, Kulturno-ovijesni muzej, Dubrovnik

Figure 20. Front side of the chest of drawers from the Cultural History Museum in Dubrovnik

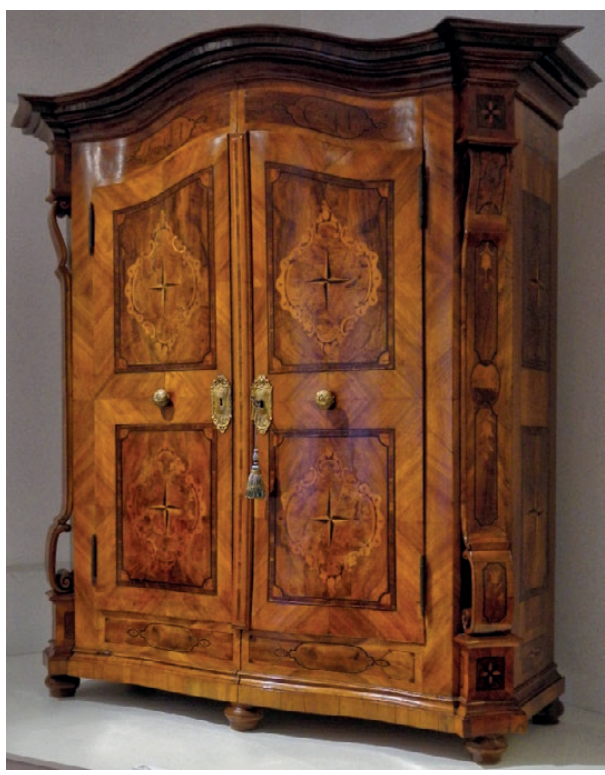

Slika 21. Ormar iz Kulturno-povijesnog muzeja u Dubrovniku Figure 21. Cabinet from the Cultural History Museum in Dubrovnik

Pretpostavlja se da je riječ o prikazu antičke božice Dijane (Artemide), koja se na prikazima pojavljuje s lukom i strijelom kao glavnim atributima.

Motiv se ponavlja na ladicama, gdje su vitice sa florealnim motivima na bočnim stranama te središnje polje s figurativnim prizorom unutar vitičastog okvira čije "„S" volute asociraju na "naslonjač“ na kojem se „odmara“ ženski lik (Slika 20).

Na slici 21. prikazan je ormar (inv. br. DUM KPM P-373), izrađen 1799.g. u Austriji. Materijal od kojeg je ormar izrađen je drvo bora za konstruktivne elemente. Unutarnja ladica je izrađena od orahovine. Pročelje je od korijenskog 
oraha s intarzijama od javora i ebanovine. Iz prikazanog je vidljivo da se radi o vrlo vrijednim predmetima Dubrovačkih muzeja.

\section{RASPRAVA I ZAKLJUČCI}

\section{DISCUSSION AND CONCLUSIONS}

Šume su, kao što je općenito poznato, najvrjedniji obnovljivi prirodni resurs i opće dobro od iznimnog interesa za Republiku Hrvatsku. Koliko se god pričalo i pisalo o njima uvijek se ima ponešto za dodati. Tako se i nametnula tema koja ukratko prikazuje povezanost održavanja šuma uz proizvodnju furnira do proizvoda od drva koji su dio kulturne baštine. Važnost navedenih dijelova jednog procesa nastajanja umjetničko vrijdnog namještaja primjenjuje se u restauriranju i izradi drvenih predmeta.. Da nema šuma, ne bi bilo trupaca od kojih se izrađuju visokovrijedni furniri, posebno oni s estetskim svojstvima koji proizvodima visoke dodane vrijednosti na kojima se rade intarzije povećavaju estetsku i umjetničku vrijednost.

Proizvodnja furnira u republici Hrvatskoj u 2017. godini iznosila je oko $27.000 \mathrm{~m}^{3}$, što Hrvatsku svrstava u sredinu u odnosu na druge države Europskog kontinenta, uključujući i Rusiju. Izvoz je bio oko $22.000 \mathrm{~m}^{3}$, što Hrvatsku također svrstava u sredinu po količini, no po vrijednosti izvoza (oko 52 milijuna dolara) svrstava je među sedam najvećih izvoznika (FAO,2019). Razlog tomu je isključivo u vrhunskoj kvaliteti i cijeni furnira od hrastovine. Vrste drva u Republici Hrvatskoj od kojih se proizvodi furnir su hrast, jasen, trešnja, orah, javor (javor rebraš) i druge. Iako se ne radi o velikom broju drvnih vrsta, to je velik potencijal zbog različitih mogućnosti rezanja furnira i teksture drva (čisti friz, unikatna svijetla boja, polubočnica i bočnica u boji drva, špigl, friza s diskoloracijom, razlika u boji, kvržice, bez bjeljike, bez tehničkih grešaka, natur i drugo). Proizvodnja furnira u Republici Hrvatskoj razvijena je do granice mogućnosti domaćih sirovinskih izvora (Romić, 2017). S obzirom na navedeno, evidentno je da postoje izvrsni uvjeti za proizvodnju unikatnih predmeta s intarzijama, kao i za restauriranje postojećih velikih umjetničkih vrijednosti.

Od sasvim prirodnih resursa dolazimo do umjetničke tehnike intarzije, koja se kao i šume odupire u očuvanju i održavanju svim nedaćama novoga doba. Pravilnim gospodarenjem šuma, pravilnim održavanjem kulturne baštine može se sa sigurnošću tvrditi da Republika Hrvatska ima bogatu ostvštinu za buduće generacije, kako u prirodnim resursima tako i u umjetnički izrađenim predmetima od drva. Znajući ponešto o važnsti primjene tehnike intarzija na raznovrsnim proizvodima od drva, posebice onih visoke dodane vrijednosti postavlja se pitanje koja je vrijednost tih predmeta? Vrlo je nezahvalno davati individualne procjene bez prethodnog znanja o mnogim čimbenicima vrijednosti predmeta. No ipak, muzejska procjena vrijednosti pred- meta služi za funkcioniranje muzejske djelatnosti, a ono ne mora nužno odgovarati tržišnoj vrijednosti predmeta. Za procjenu treba uzeti u obzir kulturno - povijesno podrijetlo i vrijeme nastanka. Vrlo su važne i tehničke značajke, kao i materijal od kojega je predmet izrađen i sama tehnika izrade, kakvoća predmeta, pod čime se misli na očuvanost i cjelovitost predmeta kao umjetničke tvorevine. Potrebno je uzeti u obzir i autentičnost predmeta te njegovu kulturološku vrijednost. Iz svega je vidljivo da postoji niz čimbenika koji utječu i određuju vrijednost svakog predmeta umjetničke vrijednosti kulturne baštine.

Da bi se očuvala kulturna baština u zahtjevnim procesima restauracije proizvoda od drva, u ovome radu s naglaskom na intarzije, važno je znati da je drvo materijal koji se koristi kroz povijest te mu se pravilnim održavanjem i uporabom produljuje životni vijek. Zaštitom predmeta od drva djeluje se pozitivno na okoliš i omogućuje da ugljik zarobljen u drvu tamo ostane toliko dugo koliko je proizvod u funkciji. Restauriranjem nije iskorišteno novo drvo već je staro obnovljeno. Moglo bi se zaključiti da fina umjetnost izrade intarzija započinje u šumi.

\section{LITERATURA:}

\section{REFERENCES:}

- Bajalo, I.(1953): Tehnologija drveta I, Svjetlost, Sarajevo, 150-162

- Bajalo, I.(1958): Tehnologija drveta II,Svjetlost, Sarajevo, 39-43

- Braudel, F.(1997): Sredozemlje i sredozemni svijet u doba Filipa II., 1. svezak, Zagreb, KNJIGA

- FAO: FOREST PRODUCTS Statistics. Yearbook, Rim 2019

- Gluhalić A. (2015): Moderni proizvodni procesi u proizvodnji i preradi furnira, 10th International Scientific Conference on Production Engineering, Bihać RAD

- Grael i Vila, J.,Monton Lecumberri, J.(2006): Materials, u: The ultimate guide to wood working, Lisse, The Netherlands, Rebo Publishers, 40-51

- Hloch, S.; Valiček, J.; Stoić, A.; Kozak, D.; Samardžić, I.; NovakMarcinčin, J.; Modrak, V. (2011): Rezanje mlazom vode,. Sveučilišni udžbenik, Slavonski Brod

- Ištvanić, J.; Đukić. I.; Samoščanec, M.; Šahman, M. (2001): Povijest, stanje i pravci razvitka pilanske obradbe drva u Republici Hrvatskoj.Seminarski rad, Sveučilište u Zagrebu, Šumarski fakultet

- Jordano, A.(2011): The Plus Oultra Writing Cabinet of Charles V: Expression of the Sacred Imperialism of the Austrias, 2011, Journal of Conservation and Museum Studies, 14-26

- Jovanović,D.(1948):Tehnologija tehničkog drveta,Industrijska knjiga, Beograd, 168-171

- Knežević,M.(1966): Furniri i šperovano drvo, Univerzitet u Beogradu, Beograd, drugo prošireno izdanje, Zavod za izdavanje uđbenika SR Srbije, 51

- Kolar-Dimitrijević,M.(2008):Kratak osvrt na povijest šuma Hrvatske i Slavonije, Ekonomska i ekohistorija,Zagreb

- Krpan, J., (1970.) Tehnologija furnira i ploča. Zagreb: Drugo izdanje.

- Krpan, J.(1951): Furniri i šperovano drvo, Zagreb., 5 
- Krpan, P.B.A. (2013): Iz povijesti šumarstva, Akademija šumarskih znanosti,

- Hrvatsko šumarsko društvo, Zagreb 13 - 29

- Mešić, N. 1998: Furniri, furnirske i stolarske ploče. Grafika Šaran. Zagreb: 7.

- Nikolić,S.N.(1988): Furniri i slojevite ploče, Beograd, Građevinska knjiga, 48

- Paolini, C.; (2017): L’Arte dell'Intarsiare e del Commettere, Libreria Editrice Fiorentina, Firenze, Italy, 56.

- Prpić, B., Antoljak, R,. Piškorić,O.(1976): Povijest šumarstva Hrvatske, Savez inženjera i tehničara Šumarstva i drvne industrije Hrvatske, Samobor, 303 - 341

- Ramond, P. (1989): Marquetry, France, 1989., 13-19

- Romić, R. (2017): Analiza proizvodnje furnira u republici Hrvatskoj i usporednba sa zemljama članica EU, diplomski rad, Šumarski fakultet, Zagreb

- Skliar, A. Najveće kulture svijeta- Egipat, Extrade d.o.o., Rijeka, 2005.

- Vinšćak, T. (2002): Vjerovanja o drveću u Hrvata u kontekstu slavističkih istraživanja Zagreb, 12, 25, 26, 32.
- Visković, N.(2001): Stablo i čovjek: prilog kulturnoj botanici, Antibarbarus,Zagreb

- Vrbek, B.(2011): Međunarodna godina šuma u svjetlu 50-godišnje uske suradnje hrvatske šumarske znanosti i struke,Šumarski list,Vol 135,No 13

- Osnove nauke o drvu i izrada proizvoda iz masivnog i usitnjenog drva, Zagreb, 1985. Katedra za tehnologiju drva, Šumarski fakultet u Zagrebu

- OSTALI IZVORI:

- URL 1 http://euroshpon.com.ua/en/publikatsiyi/istoriya-shponu. html

- URL2 https:/geek.hr/znanost/clanak/sume-u-hrvatskoj/

- URL 3 https://www.sumari.hr/biblio/pdf/11089.pdf

- URL 4 http://www.yannickchastang.com/tools/ Marquetry+donkey/

- URL 5 https://en.wikipedia.org/wiki/Andr\%C3\%A9_Charles_ Boulle

- URL 6: https://www.prirodniinterijer.com/intarzija-furnirumetci

\section{SUMIMARY}

The aim of this paper is to show the importance of forest protection as one of the factors of the preservation of Croatian cultural heritage. Forests are a natural resource and a source of material used in the restoration of wooden objects of artistic value and in this case it is about a specific restoration skill - the art of marquetry. Veneers as wood products obtained by technological processes play a very important role in terms of forest protection and marquetry. Wood is a material that has been used throughout history, and its proper maintenance and use prolong its lifespan. It must be emphasized that this material has distinct physical, mechanical, chemical and aesthetic properties. This paper focuses on its aesthetic properties: lustre, fineness, colour and texture. Marquetry is an art technique developed in the 13th century which has its roots in ancient Egypt and Rome. It is the art of inserting materials to decorate surfaces and objects. Veneers are the most important element of marquetry. Several methods of marquetry developed through history, of which the following stand out: Tarsia certosina, Tarsia geometrica, Tarsia a toppo, Tarsia a Incastro called Boulle's technique. This paper presents the simplest hand-made marquetry with a given motif. An overview of simple marquetry covers the entire process starting with the selection of veneer to the making of marquetry by the Boulle technique. The development of marquetry technique through history was accompanied by the development of tools for veneer processing and marquetry. Rich inlays created by Boulle's technique on authentic chests of drawers and closets of great cultural value found in the holdings of Dubrovnik museums prove that the rich cultural heritage is much more than just a one-sided approach to observing all segments mentioned in this paper which are different and yet related interdisciplinary. Therefore, it could be said that fine art rests in the forest.

KEY WORDS: wood, veneers, marquetry, marquetry techniques 